Clint Jones, Apocalyptic Ecology in the Graphic Novel: Life and the Environment after Societal Collapse

\title{
Chris Reyns-Chikuma
}

\section{(2) OpenEdition}

\section{Journals}

Electronic version

URL: http://journals.openedition.org/belphegor/3431

DOI: 10.4000/belphegor.3431

ISSN: 1499-7185

Publisher

LPCM

Electronic reference

Chris Reyns-Chikuma, "Clint Jones, Apocalyptic Ecology in the Graphic Novel: Life and the Environment after Societal Collapse", Belphégor [Online], 18-2 | 2020, Online since 16 December 2020, connection on 28 April 2021. URL: http://journals.openedition.org/belphegor/3431 ; DOI: https://doi.org/10.4000/ belphegor.3431

This text was automatically generated on 28 April 2021.

\section{(†)

Belphégor est mis à disposition selon les termes de la Licence Creative Commons Attribution - Pas d'Utilisation Commerciale - Pas de Modification 4.0 International. 
Clint Jones, Apocalyptic Ecology in the Graphic Novel: Life and the Environment after Societal Collapse

Chris Reyns-Chikuma

\section{REFERENCES}

Clint Jones, Apocalyptic Ecology in the Graphic Novel: Life and the Environment after Societal Collapse, Jefferson, MacFarland, 2020.179p. 


\section{Apocalyptic}

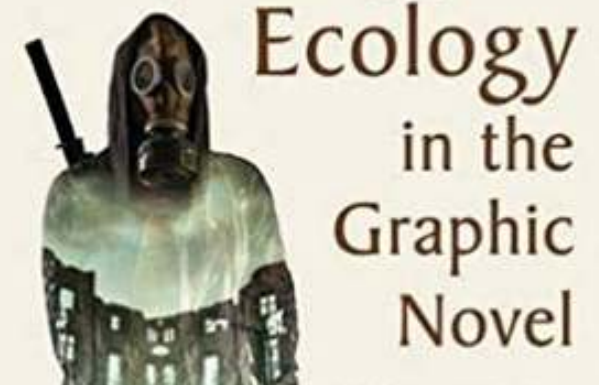

Life and the

Environment

After Societal

Collapse

CLINT

IONES

This could be a depressing reading because of its topic and the conclusions it reaches, but it is also a well-written, enlightening and useful book about the popular representations of apocalyptic ecology in some graphic novels and more generally, in popular culture. The study focuses more on the content than on the specificity of the "comics." For comics aca-fans, this perspective could disappoint, but it is nonetheless necessary in order to understand that comics in themselves are not the goal. Rather, they are a means to understand, reflect on, and if possible, improve society. And unless you are a Panglossian-Trumpian-populist-utopian for whom "all is for the best in the best of all possible worlds," the dismal state of the environment and of the lack of real will to start solving the major problems that have arisen from our society of hyperconsumption are necessarily discouraging.

2 The author clearly states his goal: "The imperative driving this critique is the need to address a lack of ecological sensitivity in popular culture, and, in redressing that lack, foster a greater sense of eco-cosmopolitanism" (14). Many people who like popular narratives in general, especially the ones analysed in this book, would probably disagree with his severe criticism. However, this study is not about the works' narrative or aesthetic qualities, which are not really commented upon, but about their weak and unrealistic representations of the post-apocalyptic world. Actually, the author argues in favor of fiction throughout the book and defends its value in helping us think about societal issues (as his critique of Plato shows, p. 33).

Alongside Cameron Ellis (professor of cultural studies), Jones, a professor of philosophy, is coeditor of The Individual and Utopia: A Multidisciplinary Study of Humanity and Perfection, 2015, and author of A Genealogy of Social Violence: Founding Murder, Rawlsian Fairness, and the Future of the Family, 2016, both with Routledge. Given his extensive works, he is well-versed in the topics of utopia, dystopia, apocalypse and ecology, and not only in an abstract way as one might expect from a 
philosopher. Without presenting cumbersome tables, or long list of stats and numbers, this book still manages to present factual data to show the dangerous escapist vagueness of these fictional representations.

4 Jones starts by trying to understand why post-apocalyptic narratives are so popular nowadays and criticizes what this popularity says about society. He identifies a major problem with these fictions: "post-apocalyptic stories are hopeful dystopian stories that use apocalyptic events as the eraser which returns us to a state of nature so that we can re-fashion the social contract" (12). Even more problematic is that our vision of the future tends to be blinded by hope for destruction that would bring a new life and a better culture, which "fetishiz[es] apocalyptic destruction as an inevitable outcome" (154). Jones then argues that what we actually need is to focus more on apocalypse and on natural disaster to be able to think more fully about society as a way of being-with, not just being-in nature (146).

5 Some information about utopias would have been useful in the introduction since the author overestimates the average reader's prerequisite knowledge on the topic. If utopia is a description of the best possible world (Thomas More's book, published in 1516 , is the most famous modern one), dystopia is a description of the problems created by a utopian vision which often manifests as the negation of freedom within a totalitarian system. Brave New World (1936) and 1984 (1948) are the two best-known modern examples. Apocalyptic ecological narratives tell stories of a group of human beings after a huge ecological disaster, e.g., natural, but most often man-made (as for Chernobyl) or both combined (as in the case of Fukushima). Often when people imagine the "worst-case-scenario" of a future to come, they do so by amplifying one or a few particularly negative aspects of the social status quo, and then allow for a lowering of the overall standard quality of life where everything else is concerned. In this way, the future becomes dystopian but remains recognizable and, in its familiarity, comprehensible. However, "[t]his approach allows the dystopia to provide stinging social criticisms of those amplified aspects of society while ignoring the subtleties, complexities, and interconnectedness of nature and human interaction" (10). Jones shows that the reality of post-apocalyptic conditions in pop culture is obscured by the intense scrutiny of and focus on the social (10).

6 The first chapter, "Whither dystopia? Why Apocalypse?" (9-30), is an introduction to the disappearance of utopia and its replacement by apocalyptic narratives. These popular cultural products do not really address the apocalyptic situation because they only present the initial disaster, then narrate the ensuing human conflicts without considering continued environmental and material deterioration. In the case of a huge disaster, the problems do not end in our modern industrial society, they multiply and even amplify. If millions of people died within a short period because of a pandemic or a massive nuclear accident, the skills necessary to maintain and protect factories would die with them. For instance, the by-products of coal mining, which is a very dirty industry, would pollute fresh water in the absence of regular monitoring (39). The same could be said for oil refineries (40), and the consequences would be even worse with hydraulic fracking (41), nuclear and chemical plants (e.g., pesticides, ...). "So where most dystopian visions might imagine terrible storms, rarely do they depict the damage as being frothy with oil or coal sludge in the aftermath of the deluge" (43). Moreover, in the two graphic novels analysed in this chapter (Remender's Tokyo Ghost and Rucka's Lazarus), the "environmental problems of utmost concern in the aftermath of an 
apocalyptic event are erased by the dystopian world being placed in a far distant future" (19).

7 Chapter two is the only one that does not deal with a specific graphic novel. In "DystoApocalyptic Hope and the Imagination" (31-48), Jones writes that classic utopias and dystopias tend to be individualistic and inert, that is, they are presented as stable and challenged only by an individual, or two (like Winston in 1984). Meanwhile, the newer depictions, which the author calls "utopias in ruins" or "dystopia-apocalypses," are collective as far as human survivors, but not the environment, are concerned. Art in general could help us to think through these problems. In Plato's Republic ( 400BCE), which presents one of the first example of secular utopia and inspired others (e.g., More's), the artist is banned from the city because mimesis, art, is seen as a deterrent from the Truth. But Plato does not consider that art is not only "mimesis but reflects our social condition back at us" (33). This is why "art," like graphic novels, is worth considering. However, writes Jones, the utopian, ever hopeful for a better future, needs to accept that we must compromise, that compromises lead to cynicism or dissatisfaction and ultimately, to the desire for destruction, that is, apocalypse, in order to mitigate the frustration of their unattainable ideal. Hence, the most problematic point is that " $[\mathrm{t}]$ he concern with various futurisms that take as their setting the postapocalyptic is that they have been presented as, and have been accepted as, desirable precisely because they offer the clearest and quickest path to a potential utopian understanding of the world" (48).

8 Chapter 3, "Pathogenic Shaped Futures, Part I: Annihilation and The Walking Dead" (49-74), is on what are probably the most famous of all these graphic stories, the very popular graphic novels (2003-2019) by Robert Kirkman, which were later adapted as an equally popular TV series (2010-still ongoing): The Walking Dead. This is also one of the most typical examples of an apocalyptic narrative that does not consider the practical realities of a disaster and its consequences. Outside some devastated zones, Kirkman depicts nature as pristine. One can (literally) see that the city's grass does not grow taller than just before the catastrophe, when it was manicured. The natural environment is implausibly static and furthermore, the graphic novel does not depict pollution or effluent from improperly closed factories.

9 Chapter 4, entitled "Pathogenic shaped futures, part II reduction and Y: The Last Man," analyzes Brian Vaughn and Pia Guerra's story (2002-2008), in which all males died except two, Yorick and his male monkey. Because this work is in color (as opposed to The Walking Dead), "very few, and quite often none, of the scars of an apocalyptic event gives Vaughn's story less of a margin for error in the representational accuracy of postapocalyptic life" (75-76). One of the central characters, Dr. Alison Mann, is a scientist and bio-geneticist, and that is what makes $\mathrm{Y}$ a hopeful dystopia. The work fails to address realistic consequences however, because if, as stats suggest, $90+\%$ of pilots and ship captains are male and this half of the population were to die, the immediate and economic impact of such a catastrophe would severely compromise key institutions (e.g., factories). Similarly, many boats containing huge quantities of dangerous products like oil would pollute the environment. But none of these scenarios factor in the story. "The world Yorick inhabits after the apocalypse should be a sprawling cesspool of destruction and waste. Given the amount of surface level damage that would exist in urban and developed areas it would not take long for drainage systems to become clogged. Clogged drainage systems would cause sewers to back up into the 
streets and home ..." (85). Furthermore, time in $Y$ is very problematic and Jones' analysis is scathing, as it points out these chronological inconsistencies (90). "The way Vaughn addresses certain apocalyptic concerns in the dialogue but does not match those concerns to a representation of the world betokens the exact problem narratives of this kind pose for a real conceptualization of the fragility of the environment and human society with a large scale, global catastrophe" (95). He then counters this vagueness with precise data about a concrete, real catastrophe, i.e., Deep Horizon oil spill in the Gulf of Mexico in 2010: "before the cleanup could be considered officially over, BP reported that it had expended more than $\$ 14$ billion, required more than 48,000 employees, and totaled more than 70 million personnel hours to accomplish its still incomplete cleanup goals. This level of concentration of money, resources, and labor would not be feasible in a post-apocalyptic world, but even if it was it would be difficult to address the numerous spills individually" (97).

11 Chapter 5 is entitled "Post-Human Life in a Post-Nuclear Age in Snowpiercer and Sweet Tooth" (101-126). Sweet Tooth is a graphic novel series published by American DC's Vertigo Imprint and created by Anglo-Canadian Jeff Lemire (script and art) between 2009 and 2013.

"Lemire's story is guilty of the same sorts of environmental omissions that vex" the previously analysed graphic narratives (102). Although the environment is not represented on a large scale, except for the urban areas occupied by survivors, the work presents the post-apocalyptic world as "unsettlingly pastoral and pristine" (103), and the characters are unrealistically able to "maintain some semblance of social order and scavenge plenty of resources to sustain themselves well even a decade into the apocalypse" (104). Gus, the protagonist, is a trans-human, that is, a better human, a conception which inherits religious beliefs in which the central character should become "salvific in both spiritually and physiologically transcendent ways" (105). Science is therefore sidetracked.

13 Snowpiercer is a 5-volume French "bande dessinée" created over a long period of time by five different people. Consequently, as noticed by Jones, there are some inconsistencies. It quickly became a classic in French culture, and then spread in the last decades with its translation and adaptation into a movie (2019) and a TV series (2020). The first point (not made by Jones) is that this negligent representation of a post-apocalyptic world is not only typical of the American cultural entertainment industry as these two graphic novels show (one entirely French, the other created by a Canadian). It is even more fundamentally an entertainment issue and also an ideological one in that humans cannot see themselves outside an anthropocentric perspective: once the catastrophe is over, the story focalizes on human society. The narrative does not capture that humanity cannot survive without non-human elements, such as animals and nature. If nature is destroyed, humanity cannot go on, much less organize in an orderly, functional and fair society. The apocalyptic event in Snowpiercer seems to be a nuclear disaster, which created the nuclear winter that covers the whole earth and forces all human survivors to live on a train. Not much is known about the outside world and we are never given an explanation on how the train is still able to function. This portrayal of nuclear disaster is not realistic because in such a scenario, no one would be able to travel across contaminated zones. The book is more like a typical socialist critique of capitalism and the class system, which is immediately 
made clear by the name of the protagonist, Proloff (prolo=proletarian and the Russian off, being reminding one of Lenin and his "Camaradoffs"). It is therefore much more concerned with intergroup struggles, shown by conflict between individuals and the hero's actions.

Chapter 6 (127-142) focuses on The Massive, with a script by Brian Wood (2012-2014). It is the last graphic novel studied in the book and it is also the one that comes closest to representing the complexity of real destruction in the case of a global catastrophe. Contrary to the previously discussed graphic narratives, The Massive tells the story of a slow but persistent breakdown of social order and therefore spends more time and visual space to represent the natural disaster rather than focusing on the resulting struggle to reconstruct a social contract. Moreover, the causes of the irreversible disaster are a complex combination of anthropogenic causes, climate change, and the amplification of other pre-apocalypse conditions linked to industrial practices and infrastructures. For example, large frames in the graphic novel are used to depict particularly harrowing instances of the "crash," the name of the disaster in the story (130). However, "the Crash world in pictures does not always match the description of the crash world" (132) in words. Consequently, "in a story crafted to be a warning, the [reader's] expectations are largely unmet" (133). "Though The Massive is decidedly a story about environmental destruction and an apocalyptic future, Wood tries to incorporate the human element into the narrative structure, but outside of Ninth Wave [the "saving" team], not many of the story's characters seem to realize they have to learn to live in concert with nature as a part of nature instead of apart from nature" (129).

Chapter 7, "Environmental Theory in an Apocalyptic Age" (143-156), argues in favor of a return to utopia rather than dystopian narratives in order to rethink how best to refashion society. It may seem that drawing out the failures of graphic novels to properly represent the post-apocalyptic world is a waste of time, after all, if the world is on the brink is there not a better way, a more meaningful way, of making these arguments than examining comic books?" (144). In the last chapter, the author addresses the problem in a much more philosophico-political perspective, which summarizes arguments made in the previous chapters. The causes of the disaster are not addressed in the stories and what is instead staged is a group of people trying to go back to where they were before the disaster. These observations could also be summarized by two quotations: “... recently anthropocentric and speciesist conceptions of humans relative to the rest of the world have separated humans from nature" (146); and "[the triumph of humankind] is [based on] a congratulatory conception that is only possible by ignoring the pillaging and destruction of nature" (153).

The difficulty of representing the horror of an apocalyptic disaster is partly similar to the representations of the Holocausts. However, what is troubling is the desire-forapocalypse that you find in apocalyptic entertainment such as the graphic novels studied here. But as Jones argues, "Indiscriminate, totalizing, mass death should not be a requirement for motivating individual and societal change" (155) and "to accomplish [the necessary changes] we need artworks and philosophies that honestly reckon with what it means to die a good death, but more importantly to live a good life" (155). These new and mostly man-made apocalypses should not only or primarily be about human beings. Instead, they should be about nature first, because without nature (even if seen narrowly as resources), there is simply no human race. 
17 The book ends with useful endnotes divided by chapters (157-172), an informative and short bibliography (173-176), and a brief index (177-179). Except for a few typos (like p. 42 , 'the them', 'on[e] the one hand', p. 129; 'Riceour' for 'Ricoeur', p. 176), this is a very good book and, I repeat, very useful for all of us responsible citizens to realize how we continue to blind ourselves to the real environmental disaster that we are producing, by just ignoring it and ironically, by consuming apocalyptic entertainment. A seconddegree escapism? 